\title{
Relationship between burden of infection in ungulate populations and wildlife/livestock interfaces
}

\author{
A. CARON ${ }^{1,2,3 *}$, E. MIGUEL ${ }^{1,2,4}$, C. GOMO ${ }^{5,6}$, P. MAKAYA ${ }^{6}$, D. M. PFUKENYI ${ }^{5}$, \\ C. FOGGIN ${ }^{6}$, T. HOVE $^{5}$ AND M. DE GARINE-WICHATITSKY ${ }^{1,2}$ \\ ${ }^{1}$ Cirad-Zimbabwe, Harare, Zimbabwe \\ ${ }^{2}$ Cirad, Montpellier, France \\ ${ }^{3}$ Mammal Research Institute, University of Pretoria, Pretoria, South Africa \\ ${ }^{4}$ CNRS, Université Lyon I, Lyon, France \\ ${ }^{5}$ Veterinary Faculty, University of Zimbabwe, Harare, Zimbabwe \\ ${ }^{6}$ Governmental Veterinary Services, Harare, Zimbabwe2013
}

Received 2 August 2012; Final revision 8 January 2013; Accepted 16 January 2013; first published online 26 February 2013

\section{SUMMARY}

In southern African transfrontier conservation areas (TFCAs), people, livestock and wildlife share space and resources in semi-arid landscapes. One consequence of the coexistence of wild and domestic herbivores is the risk of pathogen transmission. This risk threatens local livelihoods relying on animal production, public health in the case of zoonoses, national economies in the context of transboundary animal diseases, and the success of integrated conservation and development initiatives. The level of interaction between sympatric wild and domestic hosts, defining different wildlife/livestock interfaces, characterizes opportunities of pathogen transmission between host populations. Exploring the relationship between infection burden and different types of wildlife/ domestic interfaces is therefore necessary to manage the sanitary risk in animal populations through control options adapted to these multi-host systems. Here, we assessed the infection burdens of sympatric domestic cattle (Bos taurus/Bos indicus) and African buffalo (Syncerus caffer) at an unfenced interface and compared the infection burdens of cattle populations at different wildlife/ livestock interfaces in the Great Limpopo TFCA. Patterns of infection in ungulate populations varied between wild and domestic hosts and between cattle populations at different wildlife/livestock interfaces. Foot-and-mouth disease, Rift Valley fever and theileriosis infections were detected in buffalo and cattle at unfenced interfaces; bovine tuberculosis was only present in buffalo; and brucellosis and lumpy skin disease only in cattle. At unfenced interfaces, cattle populations presented significantly higher Theileria parva and brucellosis prevalence. We hypothesize that cattle populations at wildlife/livestock interfaces face an increased risk of infection compared to those isolated from wildlife, and that the type of interface could influence the diversity and quantity of pathogens shared. Additional host behavioural and molecular epidemiological studies need to be conducted to support this hypothesis. If it is confirmed, the management of wildlife/livestock interfaces will need to be considered through the prism of livestock and public health.

Key words: Brucellosis, foot-and-mouth disease (FMD), Rift Valley fever, tuberculosis (TB), wildlife/livestock interface.

\footnotetext{
* Author for correspondence: Dr A. Caron, PO Box 1378, Harare, Zimbabwe.

(Email: alexandre.caron@cirad.fr)
} 


\section{INTRODUCTION}

In Africa, arid and semi-arid ecosystems are perceived as having little agricultural value. These areas consequently have been largely neglected in major development initiatives implemented by remote political powers based in resource-rich areas. In parallel, the emergence of conservation ideology during the 20th century led to the conversion of large portions of these lands, mostly in the savannah biome, into protected areas. They were chosen mainly because resource-rich ecosystems were already being exploited for agriculture and were unsuitable for conservation. For diverse political and historical reasons, some human communities continue to live in these less productive arid and semiarid ecosystems. As a result, people and protected areas today share resource-poor landscapes which often are close to international borders and on the periphery of richer national centres [1, 2].

The recent development of transfrontier conservation areas (TFCAs) in southern Africa has shifted attention towards these resource-poor areas with the objective of integrating conservation and development in these marginalized areas [3-6]. These initiatives are expected to increase the land devoted to wildlife activities, a viable land-use option for these arid ecosystems, and will facilitate the movement and mingling of wildlife populations living in protected areas separated by national borders. However, the increased mobility of wildlife also increases the potential for conflict where there are interfaces between wildlife and human populations [6].

Diseases shared by wildlife and domestic animals are an important cause of concern for farmers, veterinary services and conservationists [7, 8]. Human populations living on the periphery of protected areas in southern Africa often rely heavily on livestock production to ensure their livelihoods [9]. In semi-arid and arid areas, where crop failure is common due to erratic rainfall [10], livestock production assumes an even more important role. However, diseases maintained or transmitted by wildlife can cause mortality and morbidity of livestock, decreasing livestock production [11, 12]. Conversely, wildlife species can be affected by diseases infecting domestic animals, which often are imported and therefore are alien species within the ecosystem [13, 14]. In the case of zoonoses, the health of rural communities with difficult access to health services can suffer from the spillover of pathogens from animals. When wildlife and domestic populations interact, opportunities therefore exist for pathogens to emerge in either direction [15].

Patterns of ecological interaction between species (e.g. direct or indirect contacts) depend on host behaviour, which is driven by environmental and biotic factors. Land-use types (e.g. protected areas, communal land) can influence interactions between species, and veterinary and conservation fences, human activities, roads and rivers can inhibit or facilitate wild and domestic movements and contacts [16]. Therefore, different wildlife/livestock interfaces, ranging from physical separations (i.e. fences) to open boundaries where animals can roam freely, influence wild and domestic interactions and the level of pathogen transmission between these populations [17].

The Great Limpopo Transfrontier Conservation Area (GLTFCA) was created in 2002 to co-manage as one ecological unit several national parks, communal land, and private land located in Mozambique, South Africa and Zimbabwe [9]. In Zimbabwe, Gonarezhou National Park (GNP), a semi-arid ecosystem, and the communal land on its periphery are part of the GLTFCA. Human/wildlife conflicts existed prior to the creation of the GLTFCA [18] but the creation of the GLTFCA is expected to result in increased wildlife densities and, consequently, more frequent wildlife/livestock/human interactions. Baseline data regarding these expected ecological and socioeconomic changes are required for the development of the most appropriate management options. For example, veterinary services need to decide how best to manage animal diseases/infections at wildlife/livestock interfaces by choosing from several management options (e.g. fence, buffer zone, no fence) $[19,20]$.

The aim of this study was to explore the infection burden in cattle populations living at different wildlife/livestock interfaces within the GLTFCA. Sympatric cattle (Bos taurus/Bos indicus) and African buffalo (Syncerus caffer) populations were tested for six important livestock diseases/infections of animal and public health and/or economic relevance in southern Africa (Table 1): bovine tuberculosis (bTB), foot-and-mouth disease (FMD), brucellosis (contagious abortion or brucellosis induced by Brucella abortus), Rift Valley fever (RVF), theileriosis, and lumpy skin disease (LSD) [21]. The Theileria species tested for in this instance was Theileria parva as this species is known to be hosted in buffalo and to cause corridor disease in cattle in the region [22]. Three 
Table 1. Selected pathogens and associated diseases in this study: susceptible hosts, reservoirs and impact

\begin{tabular}{|c|c|c|c|c|c|}
\hline & Disease & Reservoir & Transmission & $\begin{array}{l}\text { Effect on } \\
\text { susceptible } \\
\text { species }\end{array}$ & $\begin{array}{l}\text { Importance } \\
\text { of disease }\end{array}$ \\
\hline Brucella abortus & Brucellosis & African buffalo? & $\begin{array}{l}\text { Contact with } \\
\text { abortion product }\end{array}$ & Abortion & $\begin{array}{l}\text { Zoonosis, local } \\
\text { animal production }\end{array}$ \\
\hline $\begin{array}{l}\text { Mycobacterium } \\
\text { bovis }\end{array}$ & $\begin{array}{l}\text { Bovine } \\
\text { tuberculosis }\end{array}$ & $\begin{array}{l}\text { African buffalo, } \\
\text { cattle }\end{array}$ & $\begin{array}{c}\text { Environmental, } \\
\text { direct contact }\end{array}$ & $\begin{array}{c}\text { Morbidity; } \\
\text { mortality }\end{array}$ & $\begin{array}{l}\text { Zoonosis, local } \\
\text { animal production }\end{array}$ \\
\hline Theileria parva & Theileriosis & African buffalo & Vector-borne & Mortality & $\begin{array}{l}\text { Local animal } \\
\text { production }\end{array}$ \\
\hline $\begin{array}{l}\text { Rift Valley } \\
\text { fever virus }\end{array}$ & $\begin{array}{l}\text { Rift Valley fever } \\
\text { infection }\end{array}$ & $\begin{array}{l}\text { Unknown } \\
\text { (mosquito } \\
\text { population?) }\end{array}$ & $\begin{array}{l}\text { Vector-borne, } \\
\text { direct contact? }\end{array}$ & Mortality & $\begin{array}{l}\text { Zoonosis, local } \\
\text { animal } \\
\text { production }\end{array}$ \\
\hline $\begin{array}{l}\text { Foot-and-mouth } \\
\text { disease virus }\end{array}$ & $\begin{array}{l}\text { Foot-and-mouth } \\
\text { disease infection }\end{array}$ & $\begin{array}{l}\text { African buffalo, } \\
\text { cattle }\end{array}$ & $\begin{array}{l}\text { Direct contact, } \\
\text { environmental? }\end{array}$ & Morbidity & International trade \\
\hline $\begin{array}{l}\text { Lumpy skin } \\
\text { disease virus }\end{array}$ & $\begin{array}{l}\text { Lumpy skin } \\
\text { disease }\end{array}$ & Unknown & Vector-borne? & $\begin{array}{c}\text { Morbidity, } \\
\text { mortality }\end{array}$ & $\begin{array}{l}\text { Local animal } \\
\text { production }\end{array}$ \\
\hline
\end{tabular}

other cattle populations living at different wildlife/ livestock interfaces $(n=2)$ and at no interface $(n=1)$ with wildlife were also tested for evidence of the presence of pathogens (no wild species were sampled in these three sites). These different types of wildlife/livestock interfaces corresponded to sites with: (1) no wild ungulates, resulting in no direct interaction between wild and domestic ungulates, referred to hereafter as 'no interface'; (2) a well-maintained fence at the interface preventing direct contact between buffalo and cattle, referred to hereafter as 'fenced interface'; and (3) no fence or a damaged fence, resulting in potential high permeability of the interface, hereafter referred to as 'unfenced interface'. The point prevalences of the selected infections in the various host populations were measured and their implications were discussed in relation to their modes of transmission and control options.

\section{METHODS}

\section{Study area}

The South East Lowveld (SEL) of Zimbabwe is characterized by low elevations, high temperatures, and low and erratic rainfall (on average $<600 \mathrm{~mm}$ per year) [23], but also by patches of fertile, irrigable soil [24]. The region is comprised of a mosaic of land tenures including communal lands, re-settled small-scale agricultural plots, commercial agriculture, large-scale privately owned wildlife conservancies, and state-owned protected areas (Fig. 1) [25, 26].

\section{Study sites and interface types}

\section{Unfenced interface}

Malipati village $\left(22^{\circ} 04^{\prime} \mathrm{S}, 31^{\circ} 25^{\prime} \mathrm{E}\right)$ is located at the southern border of GNP on Sengwe communal land [27]. The park boundary lies a few hundred metres from the village. A veterinary fence was erected in 1985 along the park border to prohibit cattle/buffalo contacts, mainly to prevent the transmission of FMD. However, the fence is mostly ineffective at present because it has been damaged extensively by wildlife and people (illegally entering the park or using the wire to make poaching devices; A. Caron, personal communication).

Pesvi village $\left(22^{\circ} 20^{\prime} \mathrm{S}, 31^{\circ} 12^{\prime} \mathrm{E}\right)$ is located on the northern shore of the Limpopo River, which separates South Africa and Zimbabwe. With the exception of seasonal flooding of the Limpopo, which hinders large ungulates from crossing the international boundary for a few months every year, there is no physical barrier between Pesvi and Kruger National Park (KNP) lying on the other side of the river in South Africa.

At these two unfenced interfaces, road counts of wild and domestic ungulates at various seasons indicate that wild ungulates are present. Buffalo density in the northern part of KNP is higher than in the GNP $\left(1.4\right.$ vs. 0.5 buffalo per $\left.\mathrm{km}^{2}\right)$ [28, 29]. In informal interviews, Pesvi farmers indicated that buffalo were regularly seen crossing from KNP into Zimbabwe. Range overlap is possible in the area around Pesvi when buffalo cross the Limpopo River from KNP, 


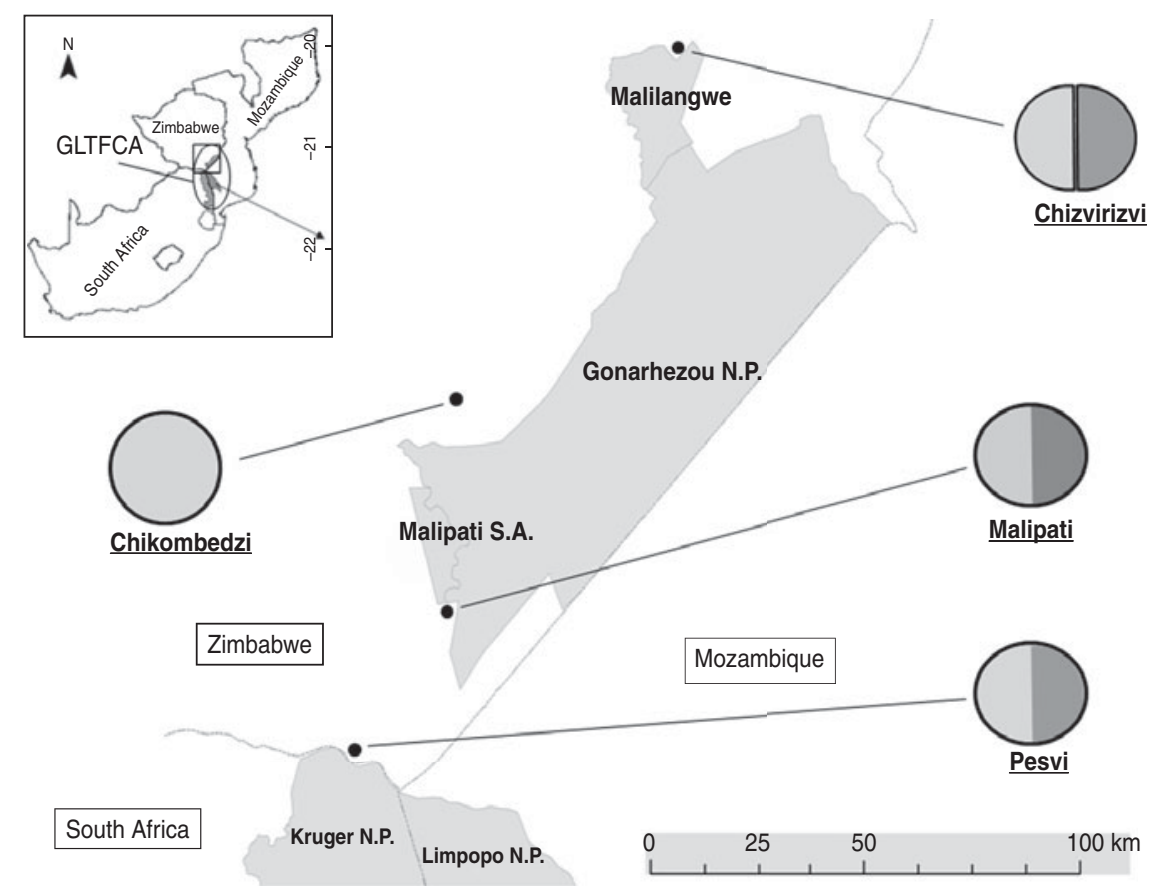

Fig. 1. Study sites and different wildlife/livestock interfaces. The map (top left) presents the south-eastern part of southern Africa encompassing Mozambique, South Africa and Zimbabwe. The Great Limpopo Transfrontier Conservation Area (GLTFCA) is represented by an ellipse and a square indicates the zoom for the rest of the Figure. On the main map, the grey area represents protected areas, N.P. indicates National Parks, Malilangwe is a conservancy and Malipati S.A. refers to the Malipati Safari Area, a hunting concession. The single line represents international borders. Each village representing a sampling unit in the study is indicated by a black dot and the circle linked to this dot refers to the type of wildlife/livestock interface: light grey represents livestock and dark grey represents wildlife; the double vertical line separating the circle indicates a fenced interface and a difference in level of shading represents an interface with no fence.

and in Malipati when buffalo cross the Mwenezi River from GNP to reach the communal land or when cattle cross the river to enter the parks. According to local farmers, the intensity of wildlife/livestock interaction at the Pesvi interface is higher than at the Malipati interface. Therefore, wildlife and domestic ungulates are sympatric and potentially in contact in these two sites.

\section{Fenced interface}

Chizvirizvi village $\left(20^{\circ} 59^{\prime} \mathrm{S}, 32^{\circ} 01^{\prime} \mathrm{E}\right)$ is located on the periphery of the Malilangwe conservancy, $405 \mathrm{~km}^{2}$ of private land dedicated to wildlife tourism lying next to the northern boundary of GNP that is surrounded by a well-maintained game fence. This fence is regularly maintained by the conservancy staff and can be assumed to be largely ungulate-proof. The conservancy hosts the full range of African wild ungulates occurring in the area. Large ungulates such as buffalo have never been observed outside the fence in the surrounding communal land area (M. de GarineWichatitsky, unpublished data). On the other side of the fence, the Chizvirizvi village hosts domestic species. The fence creates a physically defined interface separating buffalo and livestock populations.

\section{No interface}

Chikombedzi communal land $\left(21^{\circ} 40^{\prime} \mathrm{S}, 31^{\circ} 19^{\prime} \mathrm{E}\right)$ is located $15 \mathrm{~km}$ from the northwestern boundary of GNP. Wild ungulates are absent in the Chikombedzi area and this site was considered to be a control site with no wildlife/livestock interactions [road counts were performed with only one observation of a steenbok (Raphicerus campestris) recorded over a period of several years; M. de Garine-Wichatitsky, unpublished data].

Hereafter, the village name (e.g. Chikombedzi) will refer to the cattle population sampled in that area.

\section{Sampling}

The sampling objective was to: (1) collect a snapshot sample of sympatric buffalo and cattle populations; (2) collect samples of cattle populations at the 
different wildlife/livestock interfaces. Cattle herds can be accessed and counted during routine dipping events at each location, which are performed by governmental veterinary services on a regular basis (every month or at higher rates during the rainy season). In 2008, the number of cattle head per village (diptank counts) varied between 1283 and 1875 (Malipati, $n=1366$; Pesvi, $n=1875$; Chizvirizvi, $n=1444$; Chikombedzi (two diptanks), $n=1406$ and 1283), and the number of cattle head per owner was consistent across diptanks, with around 12 head per farmer (no details at the diptank level) (Chiredzi Governmental Veterinary Services, personal communication). Herd structure was consistent across diptanks, with a typical herd consisting of adult females, heifers and young animals kept as social and economic investments, and sometimes a couple of oxen for ploughing.

\section{Snapshot sampling of cattle and buffalo}

In October 2008, 120 head of cattle were sampled in Malipati and 38 African buffalo in the adjacent region of the GNP (all sampled individuals were fitted with a unique ear-tag) in collaboration with the local veterinary services and national park staff. Farmers enrolled their herd in the protocol on a voluntary basis. Four buffalo groups were selected by aerial spotting in an area as close as possible to the park border. All individuals in both species were selected randomly except for one adult female per cattle herd and three adult females per buffalo group (to fit radio collars). Cattle were sampled at the diptank as described by Gomo et al. [27]. Buffalo were captured using a standard immobilization protocol as described previously [30]. In November 2009, 10 buffalo captured during the initial sampling were re-captured and sampled again. The buffalo were immobilized using standard procedures, implemented either from the vantage point of a helicopter or from the ground after being driven into a boma structure [30]. After sample collection, anaesthesia was reversed using a chemical antidote.

\section{Cattle sampling}

In the four villages identified, cattle were sampled as described above in collaboration with the district veterinary services. Initial sampling started in August-September 2007 (Malipati and Pesvi) and lasted until the first half of 2009. The age structure of the samples can be assumed to be consistent across diptanks as any bias in the selection process would have been consistent across diptanks. Blood samples were collected from cattle following standard procedures.

\section{Sample processing and storage}

Probang samples were taken from buffalo according to standard procedures [31]. For bTB diagnosis, the single comparative intradermal tuberculin skin test (SCITT) using purified protein derivative tuberculin (PPD, Bovituber, Synbiotics Corporation, France) was performed on cattle as described by Lesslie \& Herbert [32]. Three days post-injection, skin fold thicknesses were re-measured using callipers and positivity assessed according to Shirima et al. [33]. Blood samples were left to clot at room temperature and sera separated. Sera were stored at $-4{ }^{\circ} \mathrm{C}$ in electric fridges in the field and at $-20^{\circ} \mathrm{C}$ during transport to Harare. Part of the sera were then shipped to the Agricultural Research Council, Onderstepoort Veterinary Institute (ARC-OVI) laboratory in South Africa, where serological analyses were performed.

\section{Diagnostic assays}

All serological and other diagnostic tests were performed at ARC-OVI except for the brucellosis tests which were run at the Central Veterinary Laboratory in Harare (Table 2). All of these diagnostic tests have been confirmed to be efficient in African buffalo and are commonly used on wildlife in southern Africa [22, 34-39]. The real-time polymerase chain reaction (rPCR) was used to test for T. parva on a random lot of cattle blood samples [22]. Interferon- $\gamma$ assay (IFN- $\gamma$ ) [40] was performed for buffalo and for two head of cattle that had positive SCITT results. Post-mortem examination and lymph node culture was implemented for two buffalo and two head of cattle. The two buffalo were re-captured from the initial 38 sampled buffalo (see [30] for more details) because of their positivity to the IFN- $\gamma$ assay. The two head of cattle were positive by SCITT and were selected because of their strong response to this test. FMD virus isolation was attempted on the probang samples.

\section{Statistical analyses}

All analyses were performed using R software [41]. Test for equality of proportions with continuity correction (using Pearson's $\chi^{2}$ test statistics) [42] was used to compare prevalence except when the size of 


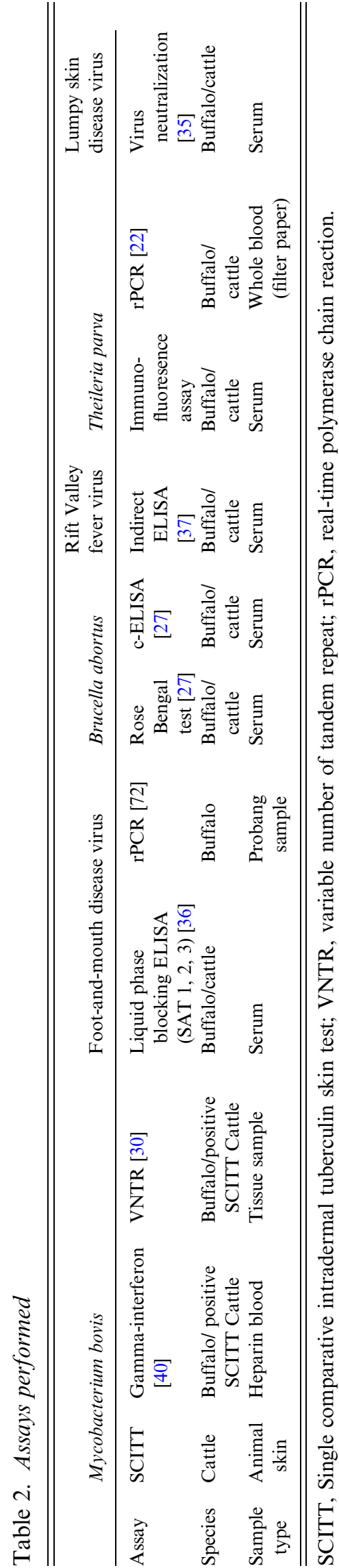

the sample was small $(n<200)$, in which case Fisher's test was used [40].

\section{RESULTS}

Bovine TB and theileriosis results are presented aggregated for the 2 years of the study. This decision was taken for two reasons: (1) for Theileria, the sampling strategy resulted in one sampling per diptank within 18 months (September 2007-February 2009); for bTB, multiple samplings per diptank were implemented but with no temporal harmonization across diptanks; (2) the chronicity and slow development of bTB and the long-term survival of Theileria antibodies render an 18-month comparison meaningless in terms of disease dynamics [43]. Rift Valley fever, FMD, and lumpy skin disease results are presented for October 2008.

\section{Bovine TB}

In November 2009, 10 of the previously tested buffalo were re-captured and tested again using the IFN- $\gamma$ assay. One was diagnosed positive for bTB although it was found negative a year earlier. Seven cattle were positive on the SCITT, with none positive in the Chikombedzi area (Table 3). The estimated prevalence for each type of interface were not significantly different pairwise $\left(\chi^{2}=0.001-0.508\right.$, D.F. $=1, \quad P=$ $0 \cdot 48-0 \cdot 98$ ). Four of these positive animals (two in Malipati and two in Pesvi) were tested with IFN- $\gamma$ assay and found negative. Two SCITT-positive animals were euthanized and necropsies were performed. No necroscopic lesions or histopathological signs compatible with bTB were observed in the organs examined and all cultures were negative. Global bTB prevalence in cattle utilizing the SCITT was $1 \cdot 17 \%$ and was significantly different from 0 (Fisher's test, $P=0 \cdot 015$ ).

\section{FMD}

FMD antibodies were detected in all of the cattle and buffalo populations (Table 3). Seropositivity for all three South African Territories (SAT) types 1, 2 and 3 was detected. Prevalence in buffalo was significantly higher than in the cattle population from Malipati and the other areas (Fisher's test, $P<0.001$ for all three tests). No significant difference was detected between cattle populations (Fisher's test, $P=0 \cdot 36-0 \cdot 78$ ). In cattle, buffalo, and a combination of cattle and 
Table 3. Diagnostic assay results for Mycobacterium bovis, foot-and-mouth disease, Brucella abortus, Rift Valley fever, Theileria parva and lumpy skin disease

\begin{tabular}{|c|c|c|c|c|c|c|}
\hline & \multicolumn{3}{|l|}{ Unfenced interface } & \multirow{3}{*}{$\begin{array}{l}\text { Fenced interface } \\
\text { Chizvirizvi } \\
\text { Cattle }\end{array}$} & \multirow{3}{*}{$\begin{array}{l}\text { No interface } \\
\text { Chikombedzi } \\
\text { Cattle }\end{array}$} & \multirow{3}{*}{$\frac{\text { Total }}{\text { Cattle }}$} \\
\hline & \multicolumn{2}{|l|}{ Malipati } & \multirow{2}{*}{$\frac{\text { Pesvi }}{\text { Cattle }}$} & & & \\
\hline & Buffalo & Cattle & & & & \\
\hline $\begin{array}{l}\text { Mycobacterium bovis (SCITT) } \\
\text { Foot-and-mouth } \\
\text { disease virus }\end{array}$ & n.a. & $\mathbf{1 \cdot 0 3} \%, 2 / 195(0 \cdot 0-2 \cdot 4)$ & 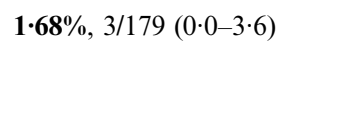 & $\mathbf{1 \cdot 6 7 \%}, 2 / 120(0 \cdot 0-4 \cdot 0)$ & $\mathbf{0} \cdot 0 \%, 0 / 104(<2 \cdot 8)$ & $\mathbf{1} \cdot \mathbf{1 7} \%, 7 / 598(0 \cdot 3-3 \cdot 1)$ \\
\hline SAT 1 & $\mathbf{9 2 \cdot 1} \%, 35 / 38(87 \cdot 7-96 \cdot 5)$ & $7 \cdot 1 \%, 5 / 70(4 \cdot 1-10 \cdot 2)$ & n.a. & $3 \cdot 3 \%, 2 / 60(1 \cdot 0-5 \cdot 7)$ & $\mathbf{1 3 \cdot 0} \%, 7 / 54(8.4-17 \cdot 6)$ & $\mathbf{7 \cdot 6} \%, 14 / 184(3 \cdot 8-11 \cdot 4)$ \\
\hline SAT 2 & $\mathbf{6 8} \cdot 4 \%, 26 / 38(60 \cdot 9-75 \cdot 9)$ & $\mathbf{1} \cdot \mathbf{4} \%, 1 / 70(0 \cdot 0-2 \cdot 8)$ & n.a. & $6 \cdot 7 \%, 4 / 60(3 \cdot 4-9 \cdot 9)$ & $\mathbf{5 \cdot 6} \%, 3 / 54(2 \cdot 4-8 \cdot 7)$ & $4 \cdot 3 \%, 8 / 184(1 \cdot 4-7 \cdot 3)$ \\
\hline SAT 3 & $\mathbf{6 5 \cdot 8} \%, 25 / 38(58 \cdot 1-73 \cdot 5)$ & $2 \cdot 9 \%, 2 / 70(0 \cdot 1-4 \cdot 8)$ & n.a. & $3 \cdot 3 \%, 2 / 60(1 \cdot 0-5 \cdot 7)$ & $3 \cdot 7 \%, 2 / 54(1 \cdot 1-6 \cdot 3)$ & $3 \cdot 3 \%, 6 / 184(0 \cdot 7-5 \cdot 8)$ \\
\hline Subtotal & $\mathbf{9 4 \cdot 7} \%, 36 / 38(91 \cdot 1-98 \cdot 3)$ & $\mathbf{1 0 \cdot 0} \%, 7 / 70(6 \cdot 4-13 \cdot 6)$ & n.a. & $6 \cdot 7 \%, 4 / 60(3 \cdot 4-9 \cdot 9)$ & $\mathbf{1 3 . 0} \%, 7 / 54(8.4-17 \cdot 5)$ & $\mathbf{9 \cdot 8} \%, 18 / 184(7 \cdot 6-12 \cdot 0)$ \\
\hline $\begin{array}{l}\text { Brucella abortus } \\
\text { (RBT and } \\
\text { c-ELISA) }\end{array}$ & $\begin{array}{l}\mathbf{0 \cdot 0} \% \\
0 / 38(<7 \cdot 8)\end{array}$ & $\begin{array}{l}\mathbf{9 \cdot 6} \%{ }^{*} \\
55 / 575(7 \cdot 2-12 \cdot 0)\end{array}$ & $\begin{array}{l}\mathbf{1 6 \cdot 0} \mathbf{*}^{*} \\
84 / 526(12 \cdot 8-19 \cdot 1)\end{array}$ & $\begin{array}{l}\mathbf{0 \cdot 0} \% * \\
0 / 60(<4 \cdot 9)\end{array}$ & $\begin{array}{l}\mathbf{1 0 \cdot 5} \%^{*} \\
19 / 180(6 \cdot 0-15 \cdot 1)\end{array}$ & $\begin{array}{l}\mathbf{1 1 \cdot 8} \% \\
158 / 1341(10 \cdot 0-13 \cdot 5)\end{array}$ \\
\hline $\begin{array}{l}\text { Rift Valley fever virus } \\
\text { (I-ELISA) }\end{array}$ & $\begin{array}{l}\mathbf{5} \cdot 3 \% \\
2 / 38(0 \cdot 0-12 \cdot 5)\end{array}$ & $\begin{array}{l}\mathbf{1 8 \cdot 3} \% \\
13 / 71(9 \cdot 2-27 \cdot 4)\end{array}$ & n.a. & $\begin{array}{l}\mathbf{8} \cdot 5 \% \\
5 / 59(1 \cdot 3-15 \cdot 6)\end{array}$ & $\begin{array}{l}7 \cdot 7 \% \\
4 / 52(0 \cdot 4-15 \cdot 0)\end{array}$ & $\begin{array}{l}\mathbf{1 2} \cdot \mathbf{1} \% \\
22 / 182(7 \cdot 3-16 \cdot 8)\end{array}$ \\
\hline $\begin{array}{l}\text { Theileria parva } \\
\text { IFA } \\
\text { rPCR }\end{array}$ & $\begin{array}{l}\mathbf{3} \cdot \mathbf{7} \%, 1 / 27(0 \cdot 0-11 \cdot 0) \\
\mathbf{8 8 \cdot 2} \%, 15 / 17(72 \cdot 4-100 \cdot 0)\end{array}$ & $\begin{array}{l}\mathbf{3 \cdot 2} \%, 1(3) / 31(0 \cdot 0-9 \cdot 5) \\
\text { n.a. }\end{array}$ & $\begin{array}{l}\mathbf{4 2} \cdot \mathbf{5} \%, 17(5) / 40(27 \cdot 0-58 \cdot 0) \\
\text { n.a. }\end{array}$ & $\begin{array}{l}\mathbf{0 . 0} \%, 0(4) / 60(<5 \cdot 0) \\
\text { n.a. }\end{array}$ & $\begin{array}{l}\mathbf{0} \cdot 0 \% 0(3) / 51(<5 \cdot 8) \\
\text { n.a. }\end{array}$ & $\begin{array}{l}\mathbf{9 \cdot 9} \%, 18(15) / 182(5 \cdot 5-14 \cdot 2) \\
\text { n.a. }\end{array}$ \\
\hline $\begin{array}{l}\text { Lumpy skin disease virus } \\
\text { (VNT) }\end{array}$ & $\begin{array}{l}\mathbf{0} \cdot 0 \% \\
0 / 21(<14 \cdot 1)\end{array}$ & $\begin{array}{l}\mathbf{5 2 \cdot 2} \% \\
35 / 67(40 \cdot 2-64 \cdot 3)\end{array}$ & n.a. & $\begin{array}{l}\mathbf{5 4 \cdot 2} \% \\
32 / 59(41 \cdot 4-67 \cdot 1)\end{array}$ & $\begin{array}{l}\mathbf{4 8} \cdot 1 \% \\
25 / 52(34 \cdot 4-61 \cdot 2)\end{array}$ & $\begin{array}{l}\mathbf{5 1} \cdot \mathbf{7} \% \\
92 / 178(44 \cdot 3-59 \cdot 0)\end{array}$ \\
\hline
\end{tabular}

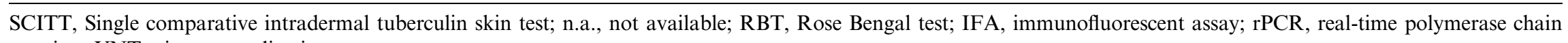
reaction; VNT, virus neutralization test.

In each cell prevalence is given in bold and higher size, immediately following by the number of positive individuals/number of individuals tested and the $95 \%$ confidence interval in parentheses.

Bovine tuberculosis SCITT results aggregated across the study period. Foot-and-mouth and Rift Valley fever and lumpy skin disease results are given for the October 2008 sampling. Brucellosis and theileriosis results are given for samples collected between August 2007 and October 2009. Positivity is decided upon consideration of positivity for both Rose Bengal and c-ELISA tests.

$*$ Results presented in [27]. 
Table 4. Qualitative summary of disease detection results of cattle populations living at various wildifellivestock interfaces and the buffalo population sampled

\begin{tabular}{|c|c|c|c|c|c|}
\hline & \multicolumn{3}{|c|}{ Unfenced interface } & \multirow{3}{*}{$\begin{array}{l}\text { Fenced interface } \\
\text { Chizvirizvi } \\
\text { Cattle }\end{array}$} & \multirow{3}{*}{$\begin{array}{l}\text { No interface } \\
\text { Chikombedz } \\
\text { Cattle }\end{array}$} \\
\hline & \multicolumn{2}{|l|}{ Malipati } & \multirow{2}{*}{$\frac{\text { Pesvi }}{\text { Cattle }}$} & & \\
\hline & Buffalo & Cattle & & & \\
\hline Mycobacterium bovis & + & 0 & 0 & 0 & 0 \\
\hline Foot-and-mouth disease & +++ & + & n.d. & + & + \\
\hline Brucella abortus & 0 & + & + & 0 & + \\
\hline Rift Valley fever & + & + & n.d. & + & + \\
\hline Theileria parva & +++ & + & +++ & 0 & 0 \\
\hline Lumpy skin disease & 0 & +++ & +++ & +++ & +++ \\
\hline
\end{tabular}

n.d., Not done.

$0=$ No detection; $+=>0 \%$ to $<20 \% ;++=>20 \%$ to $<40 \% ;+++=>40 \%$.

buffalo data, no significant difference was detected between prevalence of the different topotypes in cattle $\left(\chi^{2}=1 \cdot 05,2 \cdot 29,0 \cdot 06\right.$, D.F. $=1, P=0 \cdot 31,0 \cdot 13$, $0 \cdot 80$ ), buffalo (Fisher's test, $P=0 \cdot 74,0 \cdot 72,0 \cdot 96$ ) and a combined cattle and buffalo sample $\left(\chi^{2}=1 \cdot 94,3,0.05\right.$, D.F. $=1, P=0 \cdot 16,0 \cdot 08,0 \cdot 83$ ) (all topotype combinations tested). None of the cultures resulted in virus isolation.

\section{Brucellosis}

Results for brucellosis in cattle have already been presented $[27,44]$. No positive case was detected in the 38 buffalo sampled in 2008 and the 10 re-captured buffalo in 2009. No significant difference in brucellosis prevalence was detected between buffalo and cattle in Malipati, due mainly to the small buffalo sample size (Fisher's test, $P=0 \cdot 06$ ). A significant difference was detected when comparing all sampled cattle $v s$. buffalo (Fisher's test, $P=0 \cdot 03$ ). Brucellosis prevalence in cattle in Chizvirizvi was null and significantly different from that in Chikombedzi, Pesvi and Malipati, respectively $\left(\chi^{2}=4 \cdot 86,8 \cdot 23,4 \cdot 56\right.$, D.F. $=1$, $P=0.03,0.004,0.03)$. Finally, the prevalence in Pesvi was significantly higher than in Malipati $\left(\chi^{2}=\right.$ 7.41, D.F. $=1, P=0 \cdot 006$ ).

\section{RVF}

RVF antibodies were detected in both buffalo and cattle populations (Table 3). No difference was detected in prevalence for RVF between cattle and buffalo, and between cattle populations (Fisher's test, $P=0 \cdot 14-1$ between cattle and buffalo; Fisher's test, $P=0 \cdot 19$ and $0 \cdot 21$ for no fence and fenced interfaces).

\section{Theileriosis (T. parva)}

Theileria antibodies were detected in the unfenced cattle population and in the buffalo population. Only one buffalo was positive by immunofluorescent assay (IFA). However, 15/17 rPCR tests for buffalo were positive. Cattle in Pesvi had a significantly higher prevalence compared to all of the other cattle populations (Fisher's test, $P<0.001$ except for Malipati, $P=0.002)$. No antibody was detected in the fenced and no interface areas.

\section{LSD}

Antibodies to LSD were detected in all of the cattle populations tested, but not in the buffalo population (Table 3). No significant differences were observed between the different cattle populations (Fisher's test, $P=0 \cdot 75,0 \cdot 87,1)$ for pairs of cattle populations.

\section{Synthesis of results}

We provide a qualitative summary of the main results in Table 4 for cattle and buffalo populations according to the type of interface.

\section{DISCUSSION}

In this paper, we report evidence of infection by important pathogens in sympatric wild and domestic ungulate populations. Infection does not result systematically in disease (e.g. an infected reservoir host does not develop disease), but it is evidence of the transmission of a pathogen to a host. The pathogens investigated cause bTB, FMD, brucellosis, RVF, 
theileriosis and LSD. In Africa, brucellosis, cattle theileriosis caused by $T$. parva, and LSD can decrease local livestock production [45, 46], FMD constrains international trade [47], bTB, RVF and brucellosis can impact human health $[48,49]$ and bTB can be detrimental to wildlife health [50].

The results presented here do not offer proof of inter-species pathogen transmission. They provide a first screening of important infections in cattle populations at different wildlife/livestock interfaces that requires further investigation to understand the pathogen dynamics at play in these multi-host systems. The current knowledge about disease transmission at wildlife/livestock interfaces is still scarce. The definite proof of pathogen transmission in situ at these interfaces is technologically difficult and would require an integrated molecular, epidemiological and ecological approach. For example, molecular studies have demonstrated that bTB in KNP buffalo has originated in cattle populations [51] but so far proof of transmission from buffalo to cattle has never been demonstrated. In this study, at unfenced interfaces, cattle populations share more space and potential contacts with wildlife than with other cattle populations in other villages [52]. At the time of the study, limited market opportunities due to national economic instability and minimal transport facilities on tough dirt roads significantly curbed cattle exchanges between villages, even when the distance between villages was only a few dozen kilometres [53]. The cattle populations in each village thus could be considered to be epidemiological units that are more or less exposed to wildlife and loosely connected to other cattle populations from distant villages. The results presented here (Table 4) therefore serve to provide animal and public health stakeholders with infection occurrence, and a preliminary indication of the infections that could spread at different wildlife/livestock interfaces.

In southern Africa, the African buffalo is a reservoir for bTB, FMD and cattle theileriosis [54]. In GNP, no disease monitoring has been carried out since the late 1990s. The current results confirm the potential role of this large ungulate species in the epidemiology of bTB, FMD and theileriosis (Tables 3, 4). Veterinary management in southern Africa often aims to separate cattle from buffalo populations. FMD management has resulted in the erection of thousands of kilometres of fences in the region [55]. The presence of antibodies in the cattle populations tested, in the absence of recent vaccination against FMD (Governmental Veterinary Services, personal communication), indicates a recent circulation of FMD virus in cattle (no information on the topotypes circulating could be inferred from serological results). The veterinary fence around GNP was largely destroyed during the early 2000s. FMD outbreaks in cattle populations of the SEL of Zimbabwe have been recorded (Governmental Veterinary Services, personal communication). This FMD circulation occurred in all of the cattle populations tested in this study. These results agree with external observations that FMD has been circulating in this district since the beginning of the 21st century, and support the hypothesis that the buffalo population in GNP acts as a reservoir for FMD in cattle populations. According to this scenario, FMD epidemics started by primary outbreaks at the buffalo/cattle interface spread locally with cattle-to-cattle transmission, which would explain why cattle populations far from the wildlife/livestock interface also test seropositive. Ongoing surveillance will investigate if cattle populations at the interface are more at risk of FMD than populations that are not exposed to buffalo populations.

De Garine-Wichatitsky et al. [30] described the emergence of bTB in buffalo in GNP from a strain originating from KNP. In 2009, ten buffalo which had tested negative during the initial sampling in 2008 were re-sampled and one tested positive by IFN- $\gamma$ test, indicating the spread of the disease. Bovine TB prevalence in buffalo in southern KNP, initially introduced by cattle, has reached $35-40 \%$ [29] and seems to have stabilized. It therefore is likely that bTB prevalence in buffalo in GNP will increase in coming years. Even if SCITT prevalence was significantly different from zero when all cattle samples were combined, no SCITT-positive cattle were confirmed positive by the IFN- $\gamma$ test at post-mortem examinations and with lymph node cultures (the 'gold standard' for bTB) [56]. Therefore, the presence of bTB could not be confirmed in the cattle population sampled in our study. This absence of confirmation of bTB in cattle supports the hypothesis that bTB has been introduced only recently into the buffalo population and identifies a risk of emergence of bTB in cattle in this area (according to OIE, Zimbabwe has been considered free from bTB in cattle since 1996). Although eradication of bTB is unlikely when a wild maintenance reservoir host is infected [57, 58], a mitigation strategy should be developed and implemented to reduce the likelihood and impacts of bTB spreading to other wildlife reservoirs 
in GNP, cattle populations and eventually humans in and around the park.

Cattle theileriosis can cause severe mortality in cattle [43]. The low prevalence in buffalo detected with the IFA contrasts with the high prevalence detected with the rPCR technique. We assume that a problem occurred during the running of the IFA for buffalo as the prevalence of buffalo for theileriosis is usually similar to the one found by rPCR [22]. Cattle-to-cattle transmission is supposed to be rare. The absence of $T$. parva antibodies in cattle populations with no wildlife interface (Chikombedzi) or with an intact and large ungulate-proof fence at the wildlife/livestock interface (Chizvirizvi), coupled with their detection in cattle in Malipati and Pesvi, strongly suggests that the origin of the Theileria infection in cattle is from buffalo. The direct transmission of $T$. parva from buffalo to cattle is associated with the buffalo-derived theileriosis commonly referred to as corridor disease. This disease usually causes severe mortality in cattle [43, 59]. Only a few corridor-disease outbreaks in cattle were reported in this region prior to and during the study. To our knowledge, one outbreak of theileriosis mortality was reported in Malipati during the wet season of 2008-2009 with $<10$ cattle reported dead (Governmental Veterinary Services, personal communication). These results suggest that contrary to common belief [22], cattle populations living in close and constant contact with buffalo may support $T$. parva infection without high mortality.

Brucellosis (B. abortus) was not detected in the 38 buffalo tested in 2008 or in the 10 re-captured buffalo in 2009, which contrasts with previous studies in other areas of Zimbabwe and southern Africa [60, 61]. However, brucellosis was detected in all cattle populations except at the fenced interface [27, 44]. The absence of brucellosis in buffalo is counter-intuitive and could be explained by: (1) some cattle-herding strategies such as cattle kraaling at night which could reduce the potential for buffalo getting infected from abortion products left in the environment by cattle; (2) a possible isolation of the buffalo population in GNP from other infected buffalo populations such as the KNP buffalo population, more than $40 \mathrm{~km}$ away on the other side of the Sengwe communal land; however, this hypothesis seems to contradict the hypothesis of a spread of bTB from KNP to GNP across the Limpopo River; (3) a small buffalo sample size that would fail to detect a low prevalence in buffalo.
The role of wildlife in the epidemiology of RVF and LSD is unclear [35, 54]. Antibodies in African buffalo for both diseases have been found during previous studies [34, 62]. However, as both RVF and LSD are mainly vector-borne diseases, the epidemiology is also dependent on the population dynamics of the mosquito vectors [63]. The RVF prevalence observed in the absence of outbreaks suggests an inter-epizootic maintenance of the disease, possibly by trans-ovarian transmission of the virus in mosquitoes [64], with involvement of wildlife reservoirs, as buffalo tested positive. For LSD, no antibodies were detected in the buffalo population. High prevalence was observed in all cattle populations (Table 3), which correlates with observed LSD symptoms detected in cattle populations in 2007 (A. Caron, personal communication). These results suggest (but do not demonstrate) that the risk of disease spread from one side of the interface to the other varies among pathogens. Other factors could explain the differences observed such as cattle-to-cattle transmission between villages. However, the present study confirms that the buffalo population could represent a risk of cattle infection by bTB, FMD, theileriosis, as suggested by the literature. On the other hand, cattle could represent a risk for buffalo for brucellosis and hypothetically RVF and LSD (Table 4) if the results of this study are confirmed.

This heterogeneity of the sanitary risk across the interface can be explained by the different modes of transmission of pathogens considered. Bovine TB can be transmitted by direct or indirect contact between hosts [65]. The use of common water-holes or grazing areas by buffalo and cattle at unfenced interfaces could result in inter-species transmission of the disease. Cattle owners in Pesvi reported seeing their cattle grazing with buffalo, indicating that direct inter-species contacts are possible at unfenced interfaces. In southern Africa, FMD is transmitted exclusively by direct contact, the hot environment precluding the long distance transmission that can take place in Europe [66]. Direct contacts between buffalo and cattle were only possible at the two unfenced interfaces. Fences limit the spread of FMD viruses from buffalo to cattle by constraining host mobility, although other wild ungulate species have been involved in FMD transmission [67]. Inter-specific transmission of brucellosis requires close contact between a naive individual and abortion products within a few hours after the latter are dropped on the ground [27]. The use of a shared habitat may result in brucellosis transmission [68]. However, cattle 
herding and management strategies (e.g. cattle kraaled at night) may result in different temporal patterns of habitat use and thus asymmetric risks of brucellosis transmission. The different modes of transmission between bTB and brucellosis and the type of buffalo/ buffalo interaction between GNP and KNP could explain the different patterns of occurrence observed for both infections across the interface. This hypothesis could conciliate apparently contradictory transmission hypotheses previously presented for bTB and brucellosis. Theileriosis, RVF and LSD are all vector-borne diseases, the former is transmitted by ticks and the latter two by mosquitoes. Vectors are restricted to specific habitats and have limited movement capacities compared to their hosts. However, as long as vectors and wild and domestic hosts share common habitats, even at different times, the transmission of vector-borne diseases may occur. A fence will not limit the transmission of mosquito-borne diseases at the wildlife/livestock interface as mosquitoes can fly towards animals across the barrier. Therefore, management of these vectorborne diseases should concentrate on vector control or immunization of livestock. However, a fence could limit the spread of some ticks quite effectively, particularly those that feed on large ungulates, as ticks rely on animals to move them from one place to another. The vectors of buffalo-derived $T$. parva infection, Rhipicephalus appendiculatus and Rhipicephalus zambeziensis, are monotropic ticks which feed mainly on large domestic (cattle) and wild ungulates. Large ungulates can neither go through an intact game fence nor jump over it (with some exceptions, see [67]). It therefore is possible to control cattle theileriosis using game fences. The intact game fences in the Chizviridzi area can account for the absence of detection of T. parva.

Proper analytical approaches should be developed to study wild and domestic host interactions, controlling for external factors such as cattle-to-cattle transmission, to understand and control pathogen transmission in these multi-host systems. The development of methodologies using telemetry, molecular epidemiology and community ecology should promote relevant tools to study the ecology of disease transmission in multi-host systems [69]. Disease control measures such as fences, vaccination, and vector control, and the target of these measures in TFCAs need to be carefully considered [54]. First, control measures targeting livestock appear to be the least invasive for natural systems (even if acaricide control on cattle can shift tick host preferences [70]). Second, the difficulty of applying control measures in wildlife and a lack of experience of interventions in wildlife render the outcomes of such control measures uncertain. Third, environmental control measures, such as fencing, can compromise conservation objectives such as increasing connectivity between protected areas. These considerations imply that disease management decisions need to be debated within a framework that extends beyond a veterinary or economic perspective.

In conclusion, these results as presented in this paper on buffalo/cattle infection burden in a southern African TFCA are a valuable contribution to inferring that the type of wildlife/livestock interface can influence the diversity of pathogens and the intensity of their transmission between wild and domestic ungulate populations. However, more work is required before this conclusion can be drawn. Livestock keeping is critical for small-scale farmers living in TFCAs in southern Africa, not only from a socioeconomic point of view but also from a public health perspective. In these communities, HIV prevalence is high and consequences of the immunosupression of human populations, such as a higher susceptibility to zoonoses, are to be expected [53, 71]. In addition, poor and/or difficult access to health facilities increases the impact of diseases in human populations. The presence of RVF and brucellosis in cattle and the risk of spillover of bTB to cattle from buffalo increase the risk of transmission to humans. Integrating animal and public health surveillance and control in these ecosystems could maximize the small funds and means devoted to these activities in these remote areas [4]. Tackling the disease issue at the wildlife/livestock/human interface will be a key aspect for the success of TFCAs in southern Africa.

\section{ACKNOWLEDGEMENTS}

This work has been possible thanks to a harmonious collaboration between research (University of Zimbabwe and Cirad) and technical institutions, particularly the Governmental Veterinary Services and the Park and Wildlife Management Authority of Zimbabwe which approved the publication of this paper. The Veterinary Services of Kruger National Park in South Africa assisted in the recapture of buffalo for bTB testing. This work was conducted within the framework of the Research Platform 'Production and Conservation in Partnership' (RP-PCP) and the Animal and Human Health Environment and 
Development initiative (AHEAD). The project was funded by the European PARSEL project (No. Food 2007 137-950) and by the Ministère Français des Affaires Etrangères through the French Embassy in Zimbabwe (RP-PCP grants 2008 and 2009).

\section{DECLARATION OF INTEREST}

None.

\section{REFERENCES}

1. Dzingirai $\mathbf{V}$, et al. On the edge of state and economy. In: Andersson JA, et al., eds. Transfrontier Conservation Areas: People Living on the Edge. London, UK: Earthscan, 2013, pp. 106-22.

2. Andersson JA, Cumming DHM. Defining the edge: boundary formation and TFCAs in southern Africa. In: Andersson JA, et al., eds. Transfrontier Conservation Areas: People Living on the Edge. London, UK: Earthscan, 2013, pp. 25-61.

3. Cumming DHM. Study on the development of transboundary natural resource management areas in Southern Africa - environmental context: natural resources, land use, and conservation. Washington, DC, USA: Biodiversity Support Program, 1999.

4. Osofsky SA, Cumming HM, Kock MD. Transboundary management of natural resources and the importance of a 'one health' approach. In: Fearn E, ed. State of the Wild: A Global Portrait of Wildlife, Wildlands, and Oceans. Washington, Covelo, London: Island Press, 2008, pp. 89-98.

5. Wolmer W. Transboundary conservation: the politics of ecological integrity in the Great Limpopo Transfrontier Park. Brighton: Institute of Development Studies, 2003.

6. Andersson JA, et al. People at wildlife frontiers in Southern Africa. In: Andersson JA, et al., eds. Transfrontier Conservation Areas: People Living on the Edge. London, UK: Earthscan, 2013, pp. 1-11.

7. Cleaveland S, Laurenson MK, Taylor LH. Diseases of humans and their domestic mammals: Pathogen characteristics, host range and the risk of emergence. Proceedings of the Royal Society of London, Series B 2001; 356: 991-999.

8. de Garine-Wichatitksy M, et al. Coexisting with wildlife in Transfrontier Conservation Areas in Zimbabwe: cattle owners' awareness of disease risks and perception of the role played by wildlife. Comparative Immunology, Microbiology and Infectious Diseases. Published online 6 December 2012. doi:10.1016/j.cimid.2012.10.007.

9. Cumming DHM. Sustaining animal health and ecosystem services in large landscapes - 2nd draft: Wildlife Conservation Society, 2004.

10. Baudron F, et al. Comparative performance of conservation agriculture and current smallholder farming practices in semi-arid Zimbabwe. Field Crops Research 2012; 132: 117-128.
11. Bedelian C, Nkedianye D, Herrero M. Maasai perception of the impact and incidence of malignant catarrhal fever (MCF) in southern Kenya. Preventive Veterinary Medicine 2007; 78: 296-316.

12. Rouquet $\mathbf{P}$, et al. Wild animal mortality monitoring and human Ebola outbreaks, Gabon and Republic of Congo, 2001-2003. Emerging Infectious Diseases 2005; 11: $283-90$.

13. Cleaveland S, et al. Serological and demographic evidence for domestic dogs as a source of canine distemper virus infection for Serengeti wildlife. Veterinary Microbiology 2000; 72: 217-227.

14. Kock RA, et al. Re-infection of wildlife populations with rinderpest virus on the periphery of the Somali ecosystem in East Africa. Preventive Veterinary Medicine 2006; 75: 63-80.

15. Artois M, et al. Wildlife and emerging diseases. Revue Scientifique et Technique de l'Office International des Epizooties 2006; 25: 897-912.

16. Naidoo R, et al. Home on the range: factors explaining partial migration of African buffalo in a tropical environment. PLoS One 2012; 7: e36527.

17. Kock R. What is this infamous 'wildlife/livestock interface?' A review of current knowledge. In: Ososfsky S, et al., eds. Conservation and Development Interventions at the WildifelLivestock Interface: Implications for Wildlife, Livestock and Human Health. Gland, Switzerland, Cambridge, UK: IUCN, 2005, pp. xxxiii+220.

18. de Garine-Wichatitksy M, et al. Consequences of animals crossing the edges of Transfrontier Parks. In: Andersson JA, et al., eds. Transfrontier Conservation Areas: People Living on the Edge. London: Earthscan, 2013, pp. 137-62.

19. Ferguson K, Hanks J. Fencing impacts: a review of the environmental, social and economic impacts of game and veterinary fencing in Africa with particular reference to the Great Limpopo and Kavango-Zambezi transfrontier conservation areas. Pretoria, South Africa, 2010.

20. Sutmoller $\mathbf{P}$, et al. The foot-and-mouth disease risk posed by African buffalo within wildlife conservancies to the cattle industry of Zimbabwe. Preventive Veterinary Medicine 2000; 44: 43-60.

21. Coetzer JAW, Tustin RC. Infectious Diseases of Livestock. Pretoria, South Africa: Oxford University Press, 2004.

22. Sibeko K, et al. Development and evaluation of a realtime polymerase chain reaction test for the detection of Theileria parva infections in Cape buffalo (Syncerus caffer) and cattle. Veterinary Parasitology 2008; 155: $37-48$.

23. Gandiwa E, Zisadza P. Wildlife management in Gonarezhou National Park, Southeast Zimbabwe: climate change and implication for management. Nature \& Fauna 2010; 25: 101-10.

24. Scoones I. Coping with drought: responses of herders and livestock in contrasting savanna environments in Southern Zimbabwe. Human Ecology 1992; 20: 293-314.

25. Cumming DHM. Wildlife, livestock and food security in 
the South East Lowveld of Zimbabwe. In: Ososfsky S, et al., eds. Conservation and Development Interventions at the Wildlife/Livestock Interface: Implications for Wildlife, Livestock and Human Health. Gland, Switzerland, Cambridge, UK: IUCN, 2005, pp. xxxiii+220.

26. Clegg S. An inventory of the wildlife distribution and potenital of the South East Lowveld, Zimbabwe. Chiredzi, Zimbabwe: Malilongwe Trust, 2007.

27. Gomo C, et al. Survey of brucellosis at the wildlifelivestock interface on the Zimbabwean side of the Great Limpopo Transfrontier Conservation Area. Tropical Animal Health and Production 2012; 44: 77-85.

28. Dunham KM, et al. Aerial survey of elephants and other large herbivores in Gonarezhou National Park (Zimbabwe), Zinave National Park (Mozambique) and surrounds, 2009. Chiredzi, Zimbabwe: Park and Wildilfe Management Authority and Frankfurt Zoological Society, 2010.

29. Rodwell TC, et al. Prevalence of bovine tuberculosis in African buffalo at Kruger National Park. Journal of Wildlife Diseases 2001; 37: 258-264.

30. de Garine-Wichatitsky M, et al. Bovine tuberculosis in buffaloes, Southern Africa. Emerging Infectious Diseases 2010; 16: 884-885.

31. Van Bekkum JG, et al. Observations on the carrier state of cattle exposed to foot-and-mouth disease virus. Tijdschrift voor Diergeneeskunde 1959; 84: 1159-1164.

32. Lesslie IW, Herbert CN. Comparison of the specificity of human and bovine tuberculin PPD for testing cattle: National trial in Great Britain. Veterinary Record 1975; 96: $338-341$.

33. Shirima GM, Kazwala RR, Kambarage DM. Prevalence of bovine tuberculosis in cattle in different farming systems in the eastern zone of Tanzania. Preventive Veterinary Medicine 2003; 57: 167-172.

34. Davies FG. The possible role of wildlife as maintenance hosts for some African insect-borne virus diseases. In: Karstad L, Nestel B, Graham M, eds. Wildlife Disease Research and Economic Development. Kabete, Kenya: IDRC, 1981, pp. 24-27.

35. Hedger RS, Hamblin C. Neutralising antibodies to lumpy skin disease virus in African wildlife. Comparative Immunology, Microbiology and Infectious Diseases 1983; 6: 209-213.

36. Condy JB, et al. The duration of the foot-and-mouth disease virus carrier state in African buffalo (i) in the individual animal and (ii) in a free-living herd. Comparative Immunology, Microbiology and Infectious Diseases 1985; 8: 259-265.

37. Anderson EC, Rowe LW. The prevalence of antibody to the viruses of bovine virus diarrhoea, bovine herpes virus 1, rift valley fever, ephemeral fever and bluetongue and to Leptospira sp in free-ranging wildlife in Zimbabwe. Epidemiology and Infection 1998; 121: 441-449.

38. Kalema-Zikusoka $\mathbf{G}$, et al. A preliminary investigation of tuberculosis and other diseases in African buffalo (Syncerus caffer) in Queen Elizabeth National Park, Uganda. Onderstepoort Journal of Veterinary Research 2005; 72: 145-151.
39. Muma JB, et al. Serosurvey of Brucella spp. infection in the kafue Lechwe (Kobus leche kafuensis) of the Kafue flats in Zambia. Journal of Wildlife Diseases 2010; 46: 1063-1069.

40. Grobler DG, et al. The gamma-interferon test: its usefulness in a bovine tuberculosis survey in African buffaloes (Syncerus caffer) in the Kruger National Park. Onderstepoort Journal of Veterinary Research 2002; 69: 221-227.

41. R Development Core Team. R: A language and environment for statistical computing. R Foundation for Statistical Computing, Vienna, Austria, 2011.

42. Newcombe RG. Interval estimation for the difference between independent proportions: comparison of eleven methods. Statistics in Medicine 1998; 17: 873-890.

43. Uilenberg G. Immunization against diseases caused by Theileria parva: a review. Tropical Medicine and International Health 1999; 4: A12-A20.

44. Gomo C, et al. Detection of Brucella abortus in Chiredzi district in Zimbabwe. Onderstepoort Journal of Veterinary Research 2012; 79(1).

45. Muma JB, et al. Prevalence of antibodies to Brucella spp. and individual risk factors of infection in traditional cattle, goats and sheep reared in livestockwildlife interface areas of Zambia. Tropical Animal Health and Production 2006; 38: 195-206.

46. Latif AA, et al. Exposure of cattle immunized with different stocks of Theileria parva to buffalo-associated Theileria challenge on two game parks in Zimbabwe. Onderstepoort Journal of Veterinary Research 2001; 68: 197-201.

47. Bruckner GK, et al. Foot and mouth disease: the experience of South Africa. Revue Scientifique et Technique de l'Office International des Epizooties 2002; 21: 751-764.

48. Marcotty T, et al. Zoonotic tuberculosis and brucellosis in Africa: neglected zoonoses or minor public-health issues? The outcomes of a multi-disciplinary workshop. Annals of Tropical Medicine \& Parasitology 2009; 103: 401-411.

49. Archer BN, et al. Outbreak of Rift Valley fever affecting veterinarians and farmers in South Africa, 2008. South African Medial Journal 2011; 101: 263-266.

50. Caron A, Cross PC, du Toit JT. Ecological implications of bovine tuberculosis in African Buffalo herds. Ecological Applications 2003; 13: 1338-1345.

51. Renwick AR, White PC, Bengis RG. Bovine tuberculosis in southern African wildlife: a multi-species hostpathogen system. Epidemiology and Infection 2007; 135: 529-540.

52. Murwira A, et al. Resource gradients and movements across the edge of transfrontier parks. In: Andersson JA, et al., eds. Transfrontier Conservation Areas: People Living on the Edge. London, UK: Earthscan, 2013, pp. 123-36.

53. Giller KE, et al. Population and livelihoods on the edge. In: Andersson JA, et al., eds. Transfrontier Conservation Areas: People Living on the Edge. London, UK: Earthscan, 2013, pp. 62-88.

54. Bengis RG, Kock RA, Fisher J. Infectious animal diseases: the wildlife/livestock interface. Revue Scientifique 
et Technique de l'Office International des Epizooties 2002; 21: 53-65.

55. FAO/OIE. Progressing towards foot and mouth disease (FMD) control and OIE recognized status of SADC member states. Gaborone, Botswana: FAO/OIE, 2011.

56. Tschopp R, et al. Bovine tuberculosis at the wildlife-livestock-human interface in Hamer Woreda, South Omo, Southern Ethiopia. PLoS One 2010; 5: e12205.

57. De Lisle GW, et al. Tuberculosis in free-ranging wildlife: detection, diagnosis and management. Revue Scientifique et Technique de l'Office International des Epizooties 2002; 21: 317-334.

58. Michel AL, et al. Wildlife tuberculosis in South African conservation areas: Implications and challenges. Veterinary Microbiology 2006; 112: 91-100.

59. Latif AA, et al. Buffalo-associated Theileria parva: the risk to cattle of buffalo translocation into the Highveld of Zimbabwe. Annals of the New York Academy of Sciences 2002; 969: 275-279.

60. Madsen M, Anderson EC. Serologic survey of Zimbabwean wildlife for brucellosis. Journal of Zoo and Wildlife Medicine 1995; 26: 240-245.

61. Chaparro F, et al. A serological survey for brucellosis in buffalo (Syncerus caffer) in the Kruger National Park. Journal of South African Veterinary Association 1990; 61: 110-111.

62. Davies FG. Observations on the epidemiology of lumpy skin disease in Kenya. Journal of Hygiene (Cambridge) 1982; 88: 95-102.

63. Chihota CM, et al. Mechanical transmission of lumpy skin disease virus by Aedes aegypti (Diptera: Culicidae). Epidemiology and Infection 2001; 126: 317-321.

64. Rostal MK, et al. Identification of potential vectors of and detection of antibodies aganst Rift Valley Fever virus in livestock during interepizootic periods. American Journal of Veterinary Research 2010; 71: 524-528.
65. Tanner M, Michel AL. Investigation of the viability of $M$. bovis under different environmental conditions in the Kruger National Park. Onderstepoort Journal of Veterinary Research 1999; 66: 185-190.

66. Thomson GR, Vosloo W, Bastos AD. Foot and mouth disease in wildlife. Virus Research 2003; 91: 145-161.

67. Hargreaves SK, et al. An investigation into the source and spread of foot and mouth disease virus from a wildlife conservancy in Zimbabwe. Revue Scientifique et Technique de l'Office International des Epizooties 2004; 23: 783-90.

68. Nishi JS, Stephen C, Elkin BT. Implications of agricultural and wildlife policy on management and eradication of bovine tuberculosis and brucellosis in freeranging wood bison of northern Canada. Annals of the New York Academy of Sciences 2002; 969: 236-244.

69. Caron A, Morand S, Garine-Wichatitsky M. Epidemiological interaction at the wildlife/livestock/human interface: can we anticipate emerging infectious diseases in their hotspots? a framework for understanding emerging diseases processes in their hot spots. In: Morand S, Beaudeau F, Cabaret J, eds. New Frontiers of Molecular Epidemiology of Infectious Diseases. The Netherlands: Springer, 2012, pp. 311-32.

70. de Meeus T, et al. Swift sympatric adaptation of a species of cattle tick to a new deer host in New Caledonia. Infection, Genetics and Evolution 2010; 10: 976-983.

71. Lloyd-Smith JO, Poss M, Grenfell BT. HIV-1/parasite co-infection and the emergence of new parasite strains. Parasitology 2008; 135: 795-806.

72. Vosloo W, et al. Virus topotypes and the role of wildlife in foot and mouth disease in Africa. In: Osofsky SA, et al., eds. Conservation and Development Interventions at the WildlifelLivestock Interface: Implications for Wildlife, Livestock and Human Health. Gland, Switzerland, Cambridge, UK: IUCN, 2005, pp. 67-73. 